\title{
BADANIE PROCESÓW PAMIĘCI W MÓZGU
}

Wyobraźmy sobie, że na ulicy spotykamy człowieka, którego twarz wydaje nam się znajoma. Mamy poczucie, jakbyśmy go już kiedyś widzieli, ale nie potrafimy odnaleźć w pamięci szczegółów tej relacji. Co dzieje się wtedy w naszym mózgu? Jakie różnice zachodzą w procesie poznawczym w sytuacji, gdy tylko nam się wydaje, że kogoś znamy, a jakie, gdy rzeczywiście spotykamy naszego kolegę, przyjaciela, sąsiada?

Chociaż naukowcy od lat próbują odkryć wszystkie tajemnice naszego mózgu, wciąż niewiele o nim wiemy. W jaki sposób się uczymy, jak przebiega proces zapamiętywania i zapominania, jak kontrolowane są wszystkie czynności życiowe - to przykłady zaledwie kilku fundamentalnych zagadnień.

Znajomość procesów zachodzących w organizmie zdrowego człowieka dostarczać może inspiracji do poszukiwania sposobów leczenia osób z różnymi zaburzeniami neurologicznymi i hamowania procesów chorobowych. Wiedza z zakresu neuronauki stosowana bywa także w naukach związanych ze sztuczną inteligencją, przede wszystkim w tzw. uczeniu maszynowym. Wynikami badań żywo zainteresowani są też specjaliści zajmujący się sprzedażą. Już teraz wykorzystywane są różne metody analizy, na przykład elektrokulografia i eye-tracking, czyli badanie ruchu gałek ocznych. Dzięki niemu dowiadujemy się na przykład, w którym miejscu większość ludzi skupia uwagę, przeglądając na przykład strony internetowe. Tam właśnie umieszczane są materiały reklamowe.
Codziennie atakowani jesteśmy miliardem informacji na sekundę. Tylko niewielką część z nich rejestruje nasza świadomość. W mózgu muszą więc zachodzić pewne procesy, które pozwalają selekcjonować dane i przetwarzać je w bardzo krótkim czasie. Każdy z tych procesów jest poddawany badaniom przez poszczególne grupy naukowców specjalizujących się w danym temacie.

Szczególnie interesujące są procesy pamięci i badanie ich z wykorzystaniem specjalistycznych metod analizy czynności elektrycznej mózgu. Dr Karina Maciejewska, fizyk z Uniwersytetu Śląskiego, odbyła staż naukowy w UC Davis Center for Neuroscience w Kalifornii (USA), podczas którego rozpoczęła współpracę w grupie badawczej Dynamic Memory Lab prowadzonej przez prof. Charana Ranganatha. Wyjazd był okazją między innymi do zapoznania się ze specjalistycznymi metodami analizy sygnałów poznawczych potencjałów wywołanych (ang. Event-Related Potentials, ERP) oraz prowadzenia eksperymentów naukowych z zakresu badania pamięci u ludzi.
W swojej pracy naukowej badaczka analizuje przede wszystkim podstawowe czynności elektryczne mózgu (EEG i potencjałów wywołanych ERP) oraz innych sygnałów biologicznych u zdrowych ludzi. Dąży do pogłębienia wiedzy na temat aktywności elektrycznej ludzkiego mózgu w różnych stanach poznawczych, takich jak rozumienie języka, percepcja zmysłowa, podejmowanie decyzji czy zapamiętywanie. Takie badania pozwalają lepiej zrozumieć, jak działa mózg w stanach prawidłowego funkcjonowania. Dzięki temu pogłębia się wiedzę z zakresu psychofizjologicznej aktywności ośrodkowego układu nerwowego (OUN) i jego reakcji na bodźce zewnętrzne.

Dr Karina Maciejewska rozpoczęła w ramach stażu współpracę z grupą naukowców, którzy wykorzystywali trzy główne techniki pomiarowe, aby badać procesy pamięci długotrwałej. Analizują oni aktywność elektryczną mózgu, stosują rezonans magnetyczny pozwalający sprawdzić, które obszary mózgu aktywują się w trakcie danego procesu, i wreszcie prowadzą badania behawioralne - zapraszają grupę ochotników i, 
